This item was submitted to Loughborough's Research Repository by the author.

Items in Figshare are protected by copyright, with all rights reserved, unless otherwise indicated.

\title{
The backstage work negotiators do when communicating with persons in crisis
}

PLEASE CITE THE PUBLISHED VERSION

https://doi.org/10.1111/josl.12347

\section{PUBLISHER}

(c) Wiley

VERSION

AM (Accepted Manuscript)

\section{PUBLISHER STATEMENT}

This is the peer reviewed version of the following article: STOKOE, E. and SIKVELAND, R.O., 2019. The backstage work negotiators do when communicating with persons in crisis. Journal of Sociolinguistics, 4(2), pp. 185-208, which has been published in final form at https://doi.org/10.1111/josl.12347. This article may be used for non-commercial purposes in accordance with Wiley Terms and Conditions for Use of Self-Archived Versions.

\section{LICENCE}

CC BY-NC-ND 4.0

\section{REPOSITORY RECORD}

Stokoe, Elizabeth, and Rein Sikveland. 2019. "The Backstage Work Negotiators Do When Communicating with Persons in Crisis”. Loughborough University. https://hdl.handle.net/2134/37688. 


\section{The backstage work negotiators do when communicating with persons in crisis}

Elizabeth Stokoe and Rein Ove Sikveland

Discourse and Rhetoric Group

Centre for Research in Communication and Culture

Loughborough University

LE11 3TU

UK

(C) 2019 Accepted for publication in Journal of Sociolinguistics 


\title{
The backstage work negotiators do when communicating
}

\section{with persons in crisis}

\begin{abstract}
When a person in crisis threatens suicide, police negotiators engage them in a conversation to prevent death. Working in small teams, the primary negotiator's role is to talk directly to the person in crisis. A secondary negotiator, working 'behind the scenes', supports the ongoing negotiation. Using 31 hours of audio-recorded British negotiations, we uncover the backstage work of secondary negotiators. We use conversation analysis to identify the sequential position, linguistic form and action of the secondary negotiator's interventions on (i) the delivery (e.g., 'sound angry') and (ii) next actions (e.g., 'say please', 'try asking them to move') of the primary negotiator, and how the primary incorporates them into the negotiation. Our analysis shows that, while some suggestions were effective, others disrupted the flow of the negotiation as well as the alignment between primary negotiator and person in crisis. The paper augments current sociolinguistic understandings of the high-stakes language activity of crisis negotiation and highlights the importance of attending to linguistic features of interaction when training negotiators to work better as a team.
\end{abstract}

Keywords: suicide, crisis, negotiation, conversation analysis, communication training, live supervision. 


\section{INTRODUCTION}

This paper analyses recordings in which persons in crisis and trained police negotiators interact in crisis negotiations. In the UK, these encounters involve a prescribed team of four negotiators to support the negotiation process. The secondary negotiator's (N2) role is to support the primary negotiator (N1) who, in turn, negotiates with the person in crisis (PiC). $\mathrm{N} 2$ also monitors input from the remaining two team members (N3 and N4), including intelligence information, which they may filter into communication with N1. The secondary negotiator is often positioned in close physical proximity to the primary, to enable direct communication. However, N1-N2 conversations are generally inaudible to the PiC (and invisible, if negotiation takes place by telephone), as the secondary negotiator remains in the 'backstage'. Our interest is in how and when N2 takes a 'turn' in the unfolding negotiation, while not disrupting the progress of N1's interaction with the PiC. We explore the linguistic practices with which $\mathrm{N} 2$ takes their turn, in sequentially-organized environments, in the service of conversational actions. More broadly, we are interested in a third party's (i.e., the N2's) ability to analyse someone else's interaction (i.e., N1 and the PiC), such that they evaluate a conversational moment as requiring their input in the form of encouragement, change of action, delivery, or strategy.

We start by summarizing existing bodies of work dedicated to understanding effective communication in crisis negotiation (e.g., McMains and Mullins 2014). Negotiators deal with crises of various kinds, including hostage-taking and terrorism, as well as personal crises of the kind we examine in this paper. The latter is most common yet least studied (Charlés 2007). We will also examine the limited body of work that examines how secondary parties intervene in conversations between a different primary party and their interlocutor (e.g., Peräkylä and Vehviläinen 2003). While there are myriad descriptions of the secondary 
negotiator role (e.g., Strenz 2017), this paper is, to the best of our knowledge, the first to examine recordings of secondary negotiators in live unfolding negotiations, and one of a handful papers to study linguistic-interactional features of 'live supervision'.

\section{THE LANGUAGE OF CRISIS NEGOTIATION}

Over the past fifty years, hostage and crisis communication has been researched extensively. Crisis negotiation has become a large interdisciplinary field, with an applied focus from theory and experimentation to modelling and training. Psychologists, behavioural scientists, linguists and law enforcement professionals collaborate to understand and optimize practice. Research questions are wide-ranging, from establishing the features of different hostage situations to the behavioural patterns and psychological attributes of negotiators (see Knowles 2016). At the same time, our understanding of suicide - from cause to prevention has evolved in psychological and medical domains, often in overlap with the crisis negotiation literature. As Charlés (2007) notes, 'hostage incidents are not the primary type of critical incident with which crisis negotiators deal ... Rather, negotiators often face people in the midst of an escalated personal crisis' (p. 52). In the UK and USA, police negotiators work and are trained from Hostage and Crisis Units, and their remit incorporates crisis communication in hostage, terrorism and suicide situations.

While negotiation models make language-relevant recommendations, they rarely unpack linguistic practices in detail. One of the most cited models is the 'Behavioural Change Stairway Model' (e.g., Vecchi, Van Hasselt and Romano 2005). It outlines the relationshipbuilding process between negotiator and subject with the aim of peacefully settling critical incidents (Noesner and Webster 1997). The model consists of five stages (active listening, empathy, rapport, influence, behavioural change); the first three overlap with almost any 
articulation of 'communication skills' across diverse professional settings (e.g., Voss and Raz 2016). Skills like 'active listening' are cashed out as 'mirroring', 'summarizing', 'paraphrasing', 'emotional labelling' (e.g., Royce 2005) but not further specified in terms of actual words and turns at talk. As Rubin (2016: 9) notes, recommendations such as rapport building are 'nebulous': 'it is less clear what the linguistic features are that trainers can point to in order to help negotiators achieve'.

Access to live negotiations for research purposes can be difficult. Notwithstanding the fact that they are relatively rare events, when compared to, say, calls to emergency services, many studies of real crisis negotiation are based on single case analyses or partial datasets (e.g., Garcia 2017; Rubin 2016). Several authors have analysed publicly available materials, such as conversations between FBI negotiators and David Koresh during the 1993 Waco siege (e.g., Agne 2007; Kyunghee 2016). It is interesting, then, that in a field dedicated to the importance of communication - and language as the tool through which negotiation happens - there remains little understanding of actual crisis negotiation, and even less that focuses on what McMains and Mullins (2014: 85) describe as 'the most important role on the negotiation team' - the secondary negotiator. Given that the secondary negotiator's role must be enacted 'behind the scenes', we move on to consider the small body of research on this role, as well as work on other professional settings in which the participation framework includes a speaker remaining, somehow, backstage to another ongoing interaction.

\section{THE INTERACTIONAL BACKSTAGE}

Across the wealth of hostage and crisis negotiation literature, the secondary negotiator is mentioned frequently, but there is little explicit research on or guidance for them: McMains and Mullins (2014: 118) note an 'insufficient focus on or use of secondary negotiator'. 
Typically, the role of the $\mathrm{N} 2$ is mentioned in passing in descriptions of the overall team. For example, the N2 'listens to negotiations; gathers intelligence' (Greenstone, Kosson and Gacono 2000: 391) and 'permits the negotiator to ventilate and share some of the stress' (Schlossberg 1980: 115). McMains and Mullins (2014: 85) describe the role as a 'pipeline between the negotiation team and primary', providing moral support for the primary. Relevant to the current paper, the secondary negotiator may help the primary to 'develop verbal tactics' (ibid.: 85, emphasis added) and 'monitors the verbal interactions between hostage taker and primary negotiator ... [but] does not speak directly to the subject' (Greenstone et al 2000: 397, emphasis added). The N2, then, has an assisting role in N1's interaction with the $\mathrm{PiC}$, but is one step removed from it.

While we know hardly anything about what N2s do in crisis negotiations, there are other settings in which real-time interventions from the 'backstage' occur. Some researchers have examined the linguistic practices of what is variously called 'live supervision' (Montavlo 1973), 'co-counselling' (Silverman and Quinn 1974), or 'live open supervision' (Olson and Pegg, 1979), mostly in therapeutic and clinical contexts. Peräkylä and Vehviläinen (2003: 736) provide a definition:

In live open supervision, the counsellors work in pairs. One of them (the main counsellor) conducts the session, while the other (the co-counsellor) remains silent and observes the interaction between the main counsellor and the client or clients most of the time. Sometimes the co-counsellor intervenes, however. Her interventions are typically formatted as questions, meant for the client to answer. However, these questions are primarily addressed to the main counsellor. 
Peräkylä and Vehviläinen (2003) and Peräkylä (1995) provide detailed descriptions of how live supervision works. Depending on whether the clients can see/hear the supervisor, the supervisor may address the clients directly, as well as give instructions of what to say and do directly to the supervised. This contrasts with crisis negotiation, in which N2s do usually not address the person in crisis directly - regardless of whether they are physically co-present. Peräkylä (1995) showed how the supervisors, or co-counsellors, intervened with questions at moments when, in the co-counsellor's view, the supervised counsellor had missed an opportunity to topicalize something in the client's talk or to guide possible interpretations of the client's mental states. While the co-counsellor's questions targeted the client as answerer, they were primarily addressed to the supervised counsellor, with the client referred to in the third person. Other features emerging in these studies suggested that, while the supervisor may treat their entry into the conversation as a potential disruption (e.g., with a turn-initial 'sorry'), they also forecasted the nature of their intervention (e.g., 'I would like to ask a question'). The question format seemed to serve a dual purpose in both showing that some piece of information ought to be pursued at a particular moment in the interaction, and also how it ought to be pursued.

In a review of research on live supervision, Champe and Kleist (2003: 269) concluded that 'supervisory interruptions do not cause significant disruptions to counseling sessions or participants.' However, other researchers note that inexperienced practitioners may display a 'tendency to robotization', in which the primary therapist repeats every suggestion of the supervisor (Schwartz, Liddle and Breunlin 1988). Peräkylä (1995) found that the supervised party sometimes re-delivered questions verbally, and sometimes by shifting their gaze and body position from supervisor to client. In this way, the supervised party embodied treating the intervention as relevant while also ratifying its implementation in the unfolding interaction. 
In addition to research on live supervision, we summarize a handful of other studies in which the 'backstage' is an implicit or explicit feature. For instance, Koskela and Palukka's (2011) study of 'on the job' training for air traffic controllers includes trainers' input into trainees' communications with air traffic itself. However, in the data presented, trainers do not supply words to say, but rather reflect on what the trainee is doing in the interactional spaces between the trainee's talk with the tower or pilots, or after a task is completed (e.g., 'You erm: (.) lied a bit there', p. 308). In this setting, the tower and pilots are apparently unaware of the trainer, who remains backstage. This contrasts with settings such as artistic performances, whereby conductors or instructors may correct the performance of dancers (Keevallik 2010) or choirs (Emerson, Williamson and Wilkinson 2017) during live rehearsals. Unlike crisis negotiations, this kind of 'in course guidance' (Weeks 1996) may temporarily halt the progress of the performance.

In crisis negotiations, the N2's role is to stay firmly 'backstage'. However, as we will see at the end of this paper, regardless of whether crisis negotiations take place on the telephone or face-to-face (usually still at some distance from the PiC), the 'backstage' is collaboratively produced by all parties, including the PiC. In Goffman's (1981) terms, this produces a 'participation framework' and 'production format configuration' in which N2 may be the 'author' of turns that the N1 'animates'. So, what kind of interventions do N2s make? When do they make them, sequentially? How does their entry into the negotiation display their ongoing analysis of N1's interaction with the PiC, and by what linguistic means do they do so? By analysing the position, turn design and action of N2 suggested actions, and N1 implementations (or not) of those actions, we consider N2s' ongoing analysis of N1-PiC interaction and the effectiveness of their interventions. In so doing, we offer sociolinguistics a key demonstration of how the foundational concepts of social interaction, such as turn-taking and transition relevance, may be deployed to identify effective crisis negotiation practice - a 
language activity where interaction is central and critical exactly because someone's life is at stake.

\section{DATA COLLECTION}

A UK police Hostage and Crisis Negotiation Unit supplied audio recordings of interactions between people in crisis (PiCs) and negotiators (Ns), recorded at the scene as a routine part of their job. The recordings were stored under encryption and transcribed using Jefferson's (2004) system for conversation analysis (see Appendix). Participants were given pseudonyms; all identifying features were removed. 'Person in crisis' and 'negotiator' are the police officers' own terms for the parties involved. We refer to 'persons in crisis' by their pseudonym (e.g., "Patrick") where it is used by negotiators; otherwise we use the abbreviation 'PiC'. We refer to the primary and secondary negotiators as $\mathrm{N} 1$ and $\mathrm{N} 2$. The police supplied the data under their own research governance auspices of data processing; the project also received ethical clearance at the authors' University.

The analysis presented is based on 14 negotiations, totalling 31 hours, ranging between one and four hours in duration. In 13 cases, the PiC survived (including one where the PiC was shot by police). One case had a negative outcome (the PiC died from an accident, as the recording ends). The dataset is described in Table 1, below. 


\begin{tabular}{|c|c|c|c|c|c|c|c|c|c|c|}
\hline $\begin{array}{l}\text { Case } \\
\text { ID }\end{array}$ & $\begin{array}{l}\text { PiC } \\
\text { details }\end{array}$ & Case background & $\begin{array}{l}\text { Physical/ } \\
\text { mental health }\end{array}$ & $\begin{array}{l}\begin{array}{l}\text { Physical } \\
\text { threat }\end{array} \\
\end{array}$ & $\begin{array}{l}\text { Negotiator } \\
\text { details }\end{array}$ & $\begin{array}{l}\text { Location } \\
\text { (PiC) }\end{array}$ & $\begin{array}{l}\text { Location } \\
\text { (N) }\end{array}$ & $\begin{array}{l}\text { Physical } \\
\text { proximity }\end{array}$ & Duration & $\begin{array}{l}\text { Outcome } \\
\text { (PiC) }\end{array}$ \\
\hline HN1 & $\begin{array}{l}\text { Male, } \\
18 \text { yrs }\end{array}$ & $\begin{array}{l}\text { Self-harm; } \\
\text { Domestic abuse; } \\
\text { Social services }\end{array}$ & Medication & Knife & $\begin{array}{l}\text { N1 male, } \\
\text { N2 male }\end{array}$ & $\begin{array}{l}\text { Loft inside a } \\
\text { building }\end{array}$ & $\begin{array}{l}\text { Inside building } \\
\text { below loft }\end{array}$ & Face to face & $\begin{array}{l}3 \text { hours } 5 \\
\text { mins }\end{array}$ & $\begin{array}{l}\text { PIC comes } \\
\text { down }\end{array}$ \\
\hline HN3 & $\begin{array}{l}\text { Male, } \\
\text { adult }\end{array}$ & $\begin{array}{l}\text { Self-harm incident } \\
\text { involving the police; } \\
\text { PiC claims police is } \\
\text { trying to break into } \\
\text { his flat as cause for } \\
\text { upset. }\end{array}$ & $\begin{array}{l}\text { Medication } \\
\text { paranoia; } \\
\text { previously } \\
\text { imprisoned for } \\
21 \text { years }\end{array}$ & Kn'e & $\begin{array}{l}\text { N1 female, } \\
\text { N2 male }\end{array}$ & Inside flat & $\begin{array}{l}\text { Initially outside } \\
\text { building, then } \\
\text { inside building } \\
\text { outside the flat }\end{array}$ & $\begin{array}{l}\begin{array}{l}\text { Phone / Face } \\
\text { to face }\end{array} \\
\end{array}$ & $\begin{array}{l}2 \text { hours } \\
20 \text { mins }\end{array}$ & $\begin{array}{l}\text { PIC lets } \\
\text { negotiators in } \\
\text { his flat }\end{array}$ \\
\hline HN5 & $\begin{array}{l}\text { Femal } \\
\theta ; \\
\text { young } \\
\text { adult }\end{array}$ & $\begin{array}{l}\text { Victim of violence } \\
\text { involving the police; } \\
\text { poor experience of } \\
\text { mental health } \\
\text { hospital }\end{array}$ & $\begin{array}{l}\text { Psychotic } \\
\text { episodes in the } \\
\text { past }\end{array}$ & $\begin{array}{l}\text { Noose } \\
\text { around neck }\end{array}$ & $\begin{array}{l}\text { N1 male, } \\
\text { N2 male }\end{array}$ & Inside flat & $\begin{array}{l}\text { Outside flat } \\
\text { separated by a } \\
\text { locked grill door }\end{array}$ & Face to face & $\begin{array}{l}1 \text { hour } 20 \\
\text { mins }\end{array}$ & $\begin{array}{l}\text { PCC hands } \\
\text { over keys to } \\
\text { her flat }\end{array}$ \\
\hline HN10 & $\begin{array}{l}\text { Male, } \\
\text { adult }\end{array}$ & $\begin{array}{l}\text { Uniknown; Possibly } \\
\text { drug-related; PiC } \\
\text { talks about } \\
\text { suffering if he } \\
\text { comes down }\end{array}$ & $\begin{array}{l}\text { Medication: } \\
\text { methadone }\end{array}$ & $\begin{array}{l}\text { Knfle, } \\
\text { proximity to } \\
\text { edge of roof }\end{array}$ & $\begin{array}{l}\text { N1 male, } \\
\text { N2 male }\end{array}$ & $\begin{array}{l}\text { Behind a tree on } \\
\text { top of a building }\end{array}$ & On the ground & Face to face & $\begin{array}{l}3 \text { hours } 5 \\
\text { mins }\end{array}$ & $\begin{array}{l}\text { PYC comes } \\
\text { down }\end{array}$ \\
\hline HN11 & $\begin{array}{l}\text { Male, } \\
\text { young } \\
\text { adult }\end{array}$ & $\begin{array}{l}\text { Mental health team } \\
\text { attended earlier - } \\
\text { no response; upset } \\
\text { with mum }\end{array}$ & $\begin{array}{l}\text { Medication + } \\
\text { past } \\
\text { hospitalisation }\end{array}$ & $\begin{array}{l}\text { Wire around } \\
\text { the neck, } \\
\text { proximity to } \\
\text { edge of } \\
\text { balcony }\end{array}$ & $\begin{array}{l}\text { N1 male, } \\
\text { N2 male }\end{array}$ & $\begin{array}{l}\text { Barricaded with } \\
\text { a bike on the } \\
\text { edge of a } \\
\text { balcony }\end{array}$ & On the ground & Face to face & $\begin{array}{l}3 \text { hours } \\
40 \text { mins }\end{array}$ & $\begin{array}{l}\text { PIC eventually } \\
\text { opens door for } \\
\text { Ns to come up }\end{array}$ \\
\hline HN16 & $\begin{array}{l}\text { Male, } \\
\text { young } \\
\text { adult }\end{array}$ & $\begin{array}{l}\text { Altempted burglary, } \\
\text { upset about alleged } \\
\text { assaut by a police } \\
\text { officer }\end{array}$ & Paranoia & $\begin{array}{l}\text { Proximity to } \\
\text { edge of roof; } \\
\text { threat to } \\
\text { jump }\end{array}$ & $\begin{array}{l}\text { N1 female, } \\
\text { N2 male }\end{array}$ & $\begin{array}{l}\text { On top of } \\
\text { building (15ft } \\
\text { down) }\end{array}$ & On the ground & Face to face & 4 hours & $\begin{array}{l}\text { PC comes } \\
\text { down }\end{array}$ \\
\hline HN17 & $\begin{array}{l}\text { Male, } \\
\text { adult }\end{array}$ & Unknown & $\begin{array}{l}\text { Alcohol; } \\
\text { paracetamol } \\
\text { (Pic seemingly } \\
\text { falls asleep) }\end{array}$ & $\begin{array}{l}\text { Proximity to } \\
\text { edge of roof; } \\
\text { falling asleep }\end{array}$ & $\begin{array}{l}\text { N1 fernale, } \\
\text { N2 male }\end{array}$ & Top of roof & On the ground & Face to face & $\begin{array}{l}1 \text { hour } 50 \\
\text { mins }\end{array}$ & $\begin{array}{l}\text { PIC comes } \\
\text { down }\end{array}$ \\
\hline HN22 & $\begin{array}{l}\text { Male, } \\
\text { adult }\end{array}$ & $\begin{array}{l}\text { PIC shouting abuse } \\
\text { at the government }\end{array}$ & & $\begin{array}{l}\text { Proximity to } \\
\text { edge of root }\end{array}$ & $\begin{array}{l}\text { N1 male, } \\
\text { N2 male }\end{array}$ & $\begin{array}{l}\text { On top of } \\
\text { building }\end{array}$ & $\begin{array}{l}\text { On top of } \\
\text { another (higher) } \\
\text { building }\end{array}$ & Face to face & 45 mins & $\begin{array}{l}\text { PC comes } \\
\text { down }\end{array}$ \\
\hline HN23 & $\begin{array}{l}\text { Male; } \\
\text { adult }\end{array}$ & $\begin{array}{l}\text { Lost access to son; } \\
\text { lost job; } \\
\text { Speech impairment }\end{array}$ & & $\begin{array}{l}\text { Gun; threat } \\
\text { to shoot } \\
\text { police / } \\
\text { negotiators }\end{array}$ & $\begin{array}{l}\text { N1 female, } \\
\text { N2 male }\end{array}$ & Inside flat & $\begin{array}{l}\text { Outside flat or in } \\
\text { other building: } \\
\text { other police } \\
\text { officer right } \\
\text { outside flat }\end{array}$ & Phone & $\begin{array}{l}2 \text { hours } \\
50 \text { mins }\end{array}$ & $\begin{array}{l}\mathrm{PC} \text { is shot by } \\
\text { police and } \\
\text { survives }\end{array}$ \\
\hline HN24 & $\begin{array}{l}\text { Male, } \\
\text { older } \\
\text { adult }\end{array}$ & $\begin{array}{l}\text { Upset with police, a } \\
\text { particular police } \\
\text { officer who PIC } \\
\text { claims was abusive } \\
\text { in connection with a } \\
\text { feud with PiCs } \\
\text { energy supplier }\end{array}$ & & $\begin{array}{l}\text { Gun; threat } \\
\text { to shoot self } \\
\text { and possibly } \\
\text { others } \\
\text { (police) }\end{array}$ & $\begin{array}{l}\text { N1 male, } \\
\text { N2 male }\end{array}$ & Inside flat & $\begin{array}{l}\text { Outside flat or in } \\
\text { other building }\end{array}$ & Phone & $\begin{array}{l}1 \text { hour } 5 \\
\text { mins }\end{array}$ & PIC comes out \\
\hline HN31 & $\begin{array}{l}\text { Male; } \\
\text { adult: }\end{array}$ & $\begin{array}{l}\text { Unknown; Ns } \\
\text { seemingly cannot } \\
\text { see or hear PIC }\end{array}$ & $\begin{array}{l}\text { Some } \\
\text { medication }\end{array}$ & $\begin{array}{l}\text { Unknown; } \\
\text { close to edge }\end{array}$ & $\begin{array}{l}\text { N1 male, } \\
\text { N2 male }\end{array}$ & $\begin{array}{l}\text { Barricaded in } \\
\text { stairwell }\end{array}$ & $\begin{array}{l}\text { Further down } \\
\text { the stainell }\end{array}$ & Face to face & 53 mins & $\begin{array}{l}\text { PCC comes out } \\
\text { (dynamic entry } \\
\text { due to PCC } \\
\text { falling asleep) }\end{array}$ \\
\hline HN32 & $\begin{array}{l}\text { Male; } \\
\text { adult }\end{array}$ & $\begin{array}{l}\text { PiC taliks about all } \\
\text { that's wrong with } \\
\text { the 'system' and } \\
\text { 'today is the day' }\end{array}$ & Drinking & $\begin{array}{l}\text { Proximity to } \\
\text { edge of roof }\end{array}$ & $\begin{array}{l}\text { N1 male, } \\
\text { N2 male }\end{array}$ & On a roof & On the ground & Face to face & $\begin{array}{l}3 \text { hours } \\
25 \text { mins }\end{array}$ & PIC comes out \\
\hline HN33 & $\begin{array}{l}\text { Male; } \\
\text { adult }\end{array}$ & $\begin{array}{l}\text { Brother has } \\
\text { committed suicide a } \\
\text { year earlier }\end{array}$ & $\begin{array}{l}\text { Heavy } \\
\text { medication }\end{array}$ & $\begin{array}{l}\text { Proximity to } \\
\text { edge of roof; } \\
\text { drugged } \\
\text { state }\end{array}$ & $\begin{array}{l}\text { N1 male, } \\
\text { N2 male }\end{array}$ & $\begin{array}{l}\text { On the roof of a } \\
\text { church }\end{array}$ & On the ground & Face to face & $\begin{array}{l}1 \text { hours } \\
30 \text { mins }\end{array}$ & $\begin{array}{l}\text { Pic falls (ends } \\
\text { fatally) }\end{array}$ \\
\hline HN34 & $\begin{array}{l}\text { Male; } \\
\text { adult }\end{array}$ & $\begin{array}{l}\text { PiC has received a } \\
\text { notice from } \\
\text { Immigration Office } \\
\text { to leave the country }\end{array}$ & & $\begin{array}{l}\text { Proximity to } \\
\text { edge of roof }\end{array}$ & $\begin{array}{l}\text { N1 male, } \\
\text { N2 male }\end{array}$ & $\begin{array}{l}\text { On the roof of a } \\
\text { building }\end{array}$ & On the ground & $\begin{array}{l}\text { Phone / Face } \\
\text { to face }\end{array}$ & $\begin{array}{l}2 \text { hours } \\
25 \text { mins }\end{array}$ & $\begin{array}{l}\text { PIC comes } \\
\text { down }\end{array}$ \\
\hline
\end{tabular}

Table 1. Overview of Outcomes, Locations and relative Distance between the negotiator $(\mathrm{N})$ and person in crisis $(\mathrm{PiC})$. A phone is used temporarily in one case.

Live negotiation happens in different configurations. As Table 1 shows, the PiC may be 'face-to-face' with negotiators but at a distance (e.g., on a roof; on a phone on a roof). PiCs can often, therefore, see $\mathrm{N} 2$ and $\mathrm{N} 1$, but we will show that the parties largely maintain a participation framework in which N2 remains backstage. By 'backstage', we operationalize 
Goffman's author/animator framework: actions remain backstage when they are authored by $\mathrm{N} 2$ to $\mathrm{N} 1$ as recipient and animator but done in such a way that no response by $\mathrm{N} 1$ is expected nor is designed for a response from the PiC.

Four sections of analysis focus on, first, the identification of two types of N2 backstage actions in crisis negotiation: (i) actions designed primarily for $\mathrm{N} 1$ (directing delivery) and (ii) actions designed primarily for $\mathrm{PiC}$ (directing action). In section (iii), we examine the linguistic features within these action groups in more detail and, finally, in (iv), consider cases in which N2's backstage interventions temporarily derail the negotiation.

\section{USING CONVERSATION ANALYSIS TO IDENTIFY TYPES OF BACKSTAGE N2 TURNS}

Conversation analysis is founded on the notion that any turn of talk is an analysis of the prior; one turn is the members' analysis of the prior, and that the 'next turn proof procedure' is the 'central methodological resource for the investigation of conversation' (Sacks, Schegloff and Jefferson 1974: 728). That is, in Heritage's (2005) words, 'by producing next actions, participants show an understanding of a prior action ... that a prior turn was complete, that it was addressed to them, that it was an action of a particular type (e.g., an invitation), and so on. These understandings are (tacitly) confirmed or can become the objects of repair at any third turn in an ongoing sequence. Through this process they become mutual understandings created through a sequential architecture of intersubjectivity' (p. 105).

These core interests of conversation analysts, and core mechanics of social interaction, come to life in crisis negotiation. This is because for any and all conversation to happen, participants must monitor each other's turns for when speaker transition is possibly relevant ('transition relevance places', or TRPs) so they can take a turn, showing tacit knowledge of 
the grammatical, action-oriented and prosodic features of 'turn construction units' (TCUs). They must figure out who should talk next and when; interpret the actions delivered in a turn and make a fitted response; deal with trouble in speaking, hearing and understanding, and formulate turns from myriad word and grammatical options. In crisis negotiation, if a secondary negotiator is to participate in the ongoing interaction between two other parties, and remain backstage to that encounter, then they must engage in a kind of live conversation analysis. They must identify TCUs and the action they embody; what kind of action is fitted to any other action; where a TRP occurs, and so on, such that they may be able to insert a turn that does not disrupt the finely-calibrated and millisecond-by-millisecond timing of interaction. This requires deciding, from tacit evaluation of the ongoing interaction, that something other than its current composition of turns and actions may bring about a closer alignment between negotiator and person in crisis.

We begin by describing two sequential environments in which $\mathrm{N} 2 \mathrm{~s}$ participate in ongoing negotiations. First, in Extract 1, we show that and how N2s author a second pair part (SPP) response to a PiC's first pair part (FPP), to be animated by N1 with PiC as recipient. In Extract 2, we show how $\mathrm{N} 2$ s offer endorsement of or support to N1, with turns designed only for N1. Extract 1 comes from the early stages of a negotiation. The PiC, anonymised as Patrick, is located on top of a building near his own home. The negotiators are located below the building, such that Patrick can see both N1 and N2, although he occasionally hides from the negotiators' view behind a tree next to the building. N1's focus is to get Patrick to put down a knife he is holding and fulfil an earlier commitment to 'come down in fifteen minutes'. We join the negotiation as a changeover between negotiation team members occurs. A new N2 (speaking below) replaces the previous one.

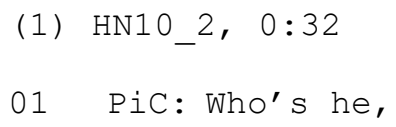


Extract 1 illustrates what happens when Patrick makes relevant N2's presence, and queries, challenges, or otherwise topicalizes it. Yet all parties simultaneously (re)establish a participation framework with N2 backstage. How does this happen?

For conversation analysts, the basic unit of interaction is the adjacency pair, in which the first pair part (FPP) works to shape the second pair part (SPP) (e.g., in exchanging greetings or in a question-answer pair). At line 01, Patrick has noticed that a new negotiator is entering the scene, but asks, as the FPP, 'Who's he', selecting N1 as next speaker. He does not ask N2, 'who are you?'. N2 maintains his backstage participation by directing his reply to $\mathrm{N} 1$, at low volume, designed only for $\mathrm{N} 1$ to hear. He produces a response as author, for N1 to animate; this is an SPP by proxy. N2's turn contains a post-positioned imperative 'just tell him', which is one practice for framing the words to be animated by N1. However, some reformulation is required; $\mathrm{N} 2$ does not intend $\mathrm{N} 1$ to do a direct repeat. $\mathrm{N} 2$ uses the pronoun 'I' not 'he', creating complex issues of recipiency. While the entire turn is designed exclusively for N1, and 'I am ... just tell him' are directed solely at N1, only 'with the police' are designed for Patrick as recipient.

Note that N2's turn is located after a long gap develops at line 02 , during which N1 has not responded to Patrick's question. The gap affords interactional space for N2 to speak without overlap but, more importantly, it reveals his ongoing analysis of the sequence launched by Patrick at line 01, including the completeness of the turn and TCU and its action. Patrick produces the first pair part of an adjacency pair ('Who's he'); a wh-question to which the preferred response, in second position, is information that identifies N2. 'Who' may be 
the name of $\mathrm{N} 2$, or his role; we found that negotiators formulate 'who they are' both ways. N2's turn at line 3 reveals his tacit analysis both of line 1 and line 2, including that 1.9 is a gap sufficiently long to reveal trouble in responding, and the kind of response that would be apposite. At line 5, N1 produces N2's suggested second pair part, but replaces N2's 'I' pronoun with 'he': 'He's with the police Patrick,'. In so doing, all three parties maintain the backstage participation framework and N1 and Patrick as interlocutors.

In contrast to Extract 1, Extract 2 shows N2 offering support or endorsement of N1 with turns designed only for N1 - but, given their function, ultimately also for the person in crisis. It comes from the same negotiation, a few seconds later. N1 is trying to get Patrick to put down a knife. Patrick has, five minutes previously, promised to come down in fifteen minutes.

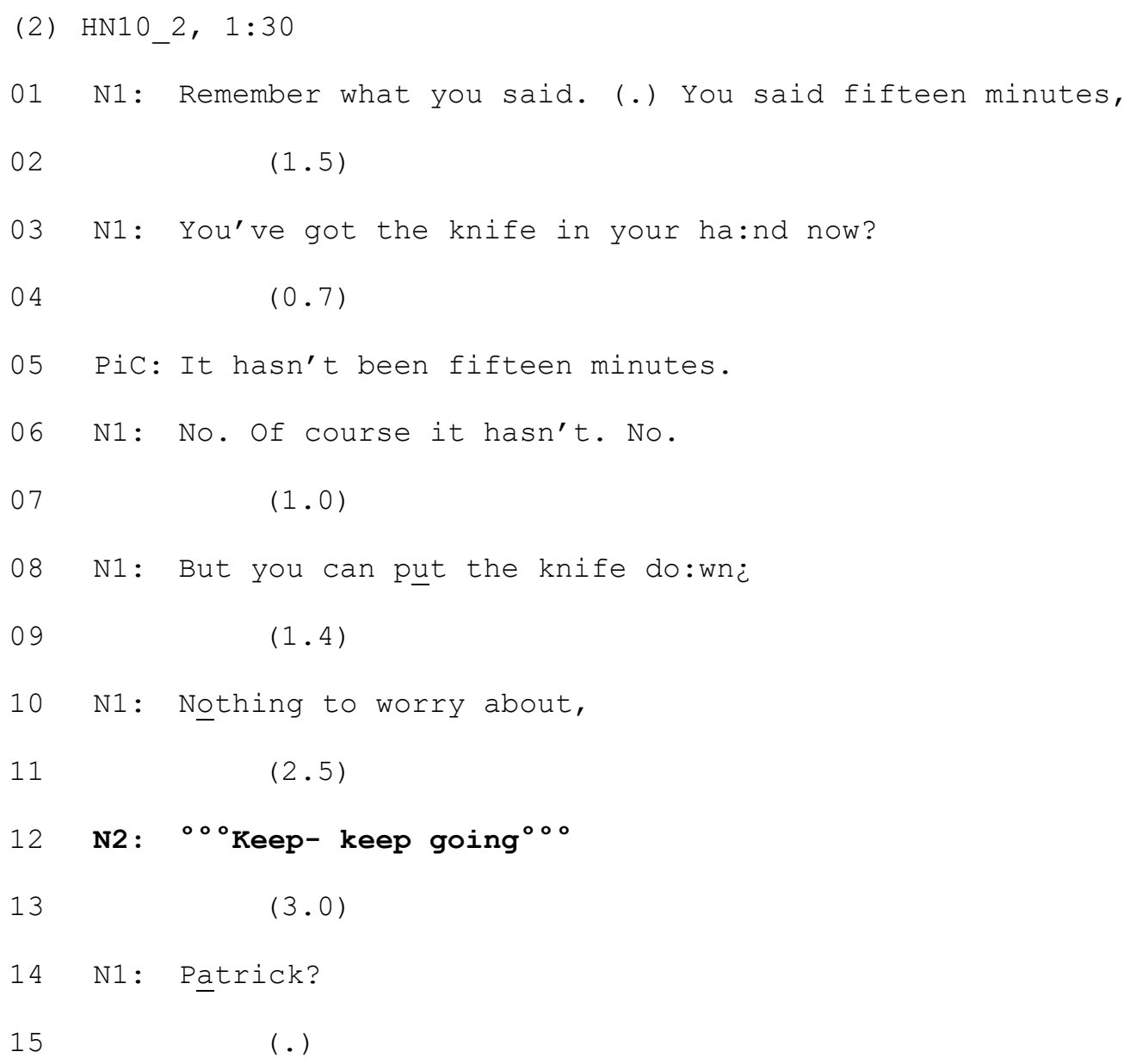




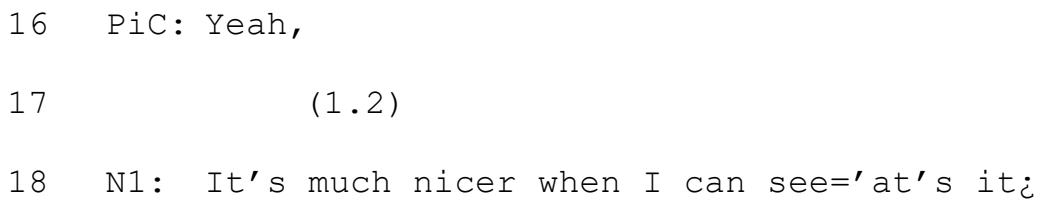

While Extract 1 illustrates how N2s may supply candidate answers to a PiC's question, his intervention in Extract 2 appears in a different sequential environment. Our focus is on N2's turn at line 12, which, like 'tell him' in Extract 1, has an imperative-formatted design: ${ }^{{ }^{\circ 0}}{ }^{K}$ Keep- keep going ${ }^{\circ 0 \circ}$. It is produced at low volume, for only N1 to hear. However, at this point, before we see what happens next, it may not be clear whether or not these are words that N2 is instructing N1 to formulate for Patrick, or whether they are designed in support of the unfolding course of action initiated by N1.

At the start of this episode, $\mathrm{N} 1$ produces a declarative turn with rising intonation, for Patrick to 'put the knife do:wn $\underset{\iota}{ }$ ' (line 08). The turn-initial 'but' marks a contrast with the agreed fact (as formulated by Patrick) that fifteen minutes have not yet passed; nevertheless, Patrick can still 'put the knife down'. That is, while agreeing that the timeline for Patrick's own promise to come down has not yet passed, $\mathrm{N} 1$ proposes that putting the knife down is independent of that promise. This is not the first time N1 has requested that Patrick put the knife down, and N1 deals with Patrick's ongoing resistance in a second turn: after a gap develops (line 09), he reassures Patrick that there is 'Nothing to worry about,'.

In response to N2's imperative to ${ }^{\circ 0 \circ}$ Keep- keep going ${ }^{\circ 0 \circ}$, N1 produces a summons to Patrick. He does not animate N2's words. Nor does N2 include components in his turn to 'say' or 'tell him', which would transform the action to one designed for N1 to be delivered to Patrick. Thus, ${ }^{\circ 00}$ Keep- keep going ${ }^{\circ 00}$ ' is an analysis and endorsement of N1's current strategy of formulating turns that are aligned with Patrick's stated intentions (to come down) and reassure him, at a moment in the interaction where Patrick does not outright reject N1's reasoning, and thereby might be on his way to align with N1's proposal. Indeed, unlike 
established conversation analytic findings about preference organization and the way delay foreshadows an upcoming dispreferred response, we have found that preferred responses are regularly delayed in settings in which one party is attempting to persuade their recipient to do something that they had previously resisted doing (Stokoe et al 2018). It appears that such delays locate a 'change of mind' in the recipient's domain; that is, an agentive decision to, say, come down, rather than agree to do so.

While N2's turn is designed to support N1 to pursue his current trajectory, rather than do something else, in fact N1 does change strategy at line 14. Given that N2's turn is not part of the negotiation itself, a gap of almost six seconds has developed between the person in crisis and N1's last turn at line 03. N1's strategy is to use the person in crisis's name 'Patrick?' - which works as a summons to get an almost immediate response (line 16). Names have this function in the negotiations, to reinitiate interaction when PiCs stop taking turns (Sikveland 2019). If N2 had said 'Say his name' at line 13, this would likely be an effective suggestion to make. Saying, ${ }^{\text {} 000}$ Keep- keep going ${ }^{\circ \circ \circ}$ does not derail the negotiation. But, as we will see later in the paper, N2's turns can easily do so.

So far, we have identified two sequential environments in which N2s participate in ongoing negotiations: (i) by authoring second pair part (SPP) responses to PiC first pair parts (FPP), to be animated by N1 with PiC as primary recipient, and (ii) by offering support to or endorsement of N1 (in the midst of N1 FPPs that do not mobilize responses) with turns designed primarily for $\mathrm{Nl}$ - but, given their function, ultimately also for PiC. In the next section, we examine further examples of the practice introduced in Extract 2, in which N2's spoken turns are, in the first instance, designed for $\mathrm{N} 1$ as primary recipient, before returning to examine more instances of N2-authored turns for N1's animation. 


\section{N2 INTERVENTIONS ON DELIVERY WITH N1 AS PRIMARY RECIPIENT}

In Extract 3, the N1 has been negotiating face-to-face, albeit at a short distance, for over an hour with the PiC, Jessica. Jessica has been slowly asphyxiating herself by hanging. Jessica's front door is open, but an additional barred security gate is locked. There have been productive moments throughout the negotiation, and Jessica has implied that she might throw the gate keys to N1. However, we join the interaction as she starts to tighten the noose, subsequently becoming unresponsive. Jessica's dog is barking; the moment is suffused with tension.

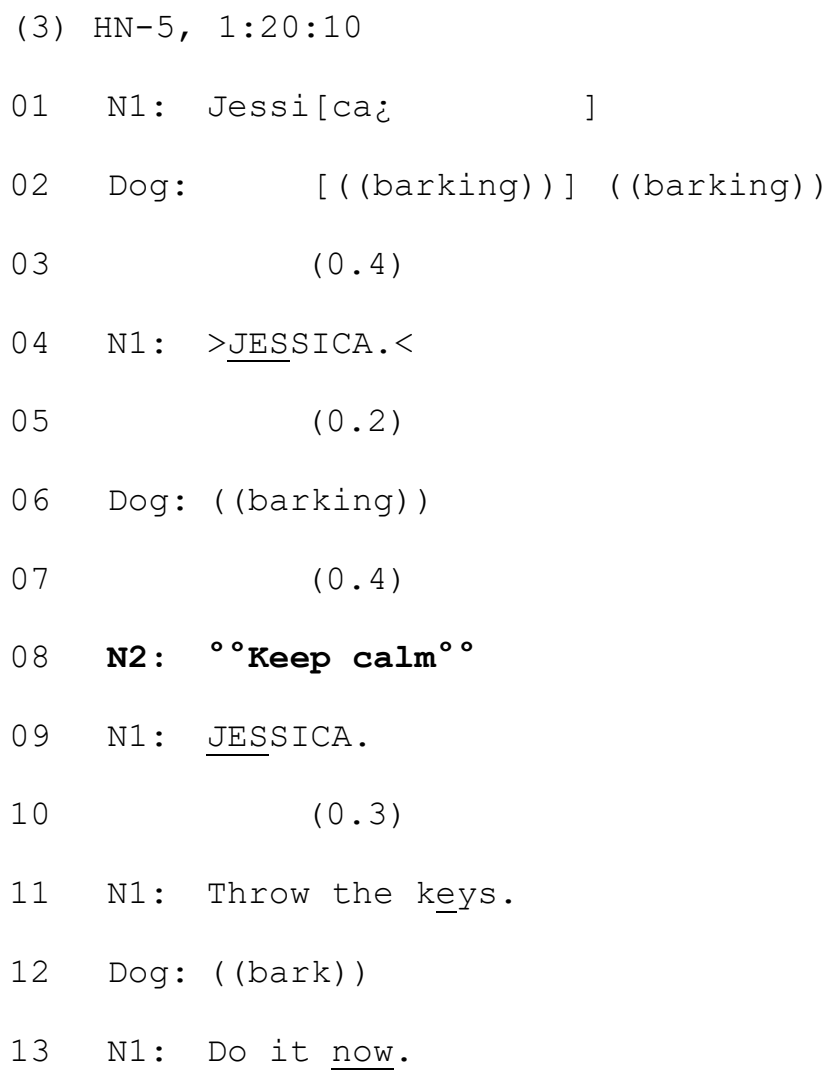


Our focus is on N2's turn at line 08: an imperative-formatted instruction to N1 to ${ }^{\circ \circ}$ Keep calm $^{\circ}$, Like Extract 2, it is delivered at low volume, and is not accompanied by features that construct it as authored words to be animated by N1. That is, N2 is not suggesting that N1 urge Jessica to 'keep calm'; in this instance, it is clear who the recipient is (unlike other cases, as we will see shortly). However, N2's turn comprises advice, or instructional guidance, for the emotional stance N1 should display. It is placed after N1 has upgraded a first summons (line 01) with greater loudness, higher pitch and a more pronounced release of the consonant initial to the first syllable (line 04). Through a phonetic analysis of the repeated delivery of address terms, Sikveland (2019) has shown that increases (or upgrades) in pitch and loudness, and more extreme articulations, are associated with an increase in danger or concern. However, neither of these FPPs receive a response. N2's intervention, with the verb 'keep' (also like Extract 2), is designed as advice to maintain the progressivity of an ongoing sequence but modify its particularities. In response to N2, N1 maintains, but does not further intensify, the prosodic features of a third summons ('JESSICA.'). Shortly after this sequence, Jessica manages to throw her keys and the negotiators enter the house and rescue her.

Extract 4 contains another example of $\mathrm{N} 2$ imperative-formatted advice about the emotional valence $\mathrm{N} 1$ might productively display. The $\mathrm{PiC}$ is positioned on top of a building after an earlier attempted burglary and has expressed fear that the police will come and 'get him'. The negotiators are positioned below the building.

(4) HN16_9, 57:14

01 N1: Hello: :?

$02 \quad(2.8)$

03 N1: Hello:: :

$04 \quad(1.8)$

05 N1: I'm he: :re? 


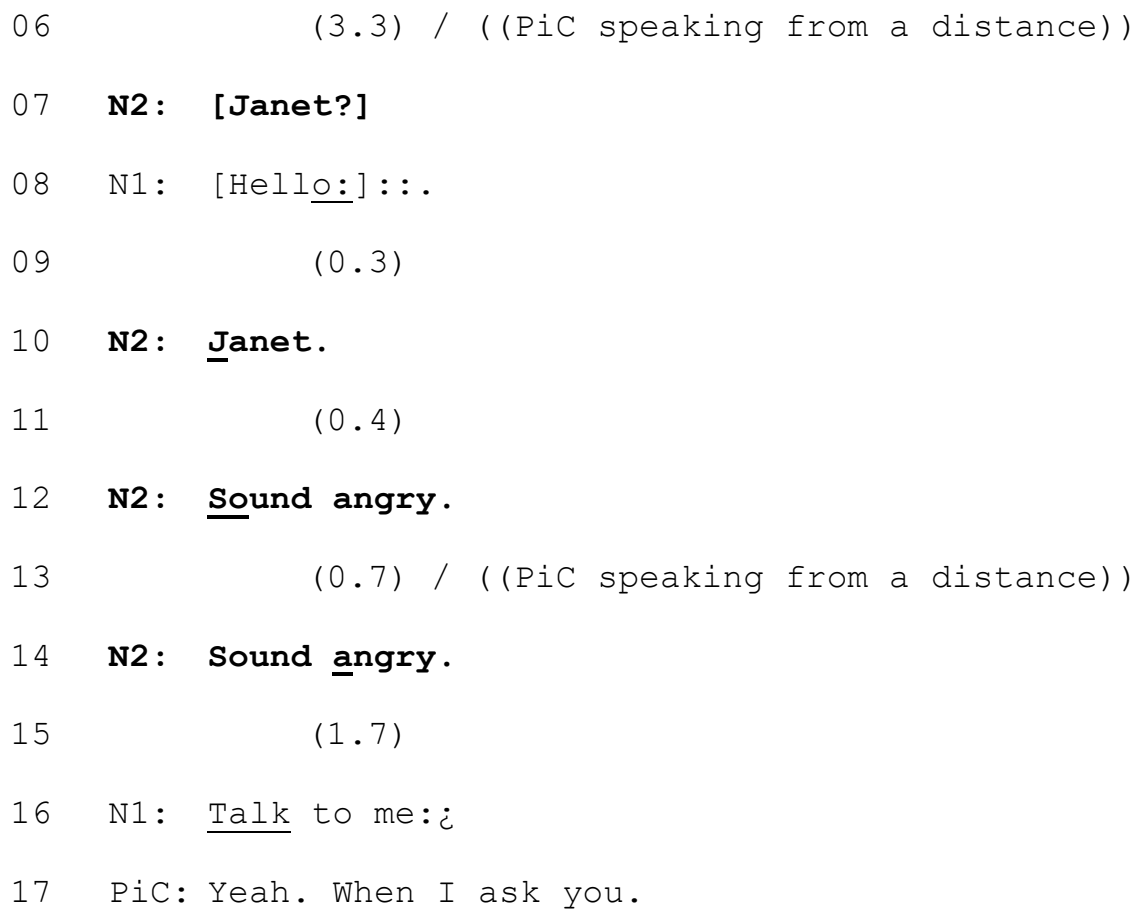

$\mathrm{N} 1$ is attempting to initiate a sequence of talk with PiC: note the multiple summons (lines 01 , $03,08)$ and indication of readiness to talk (line 05). None of these turns mobilize a response. At line 07, N2 launches a kind of 'parenthetical sequence' (Mazeland 2007), first securing N's attention with her name, 'Janet'. His repetition of 'Janet' at line 10, with slightly elevated intensity, suggests that $\mathrm{N} 2$ did not secure her recipiency in the first summons, which occurs in overlap with N1's own summons of PiC. Once he has her attention, N2 delivers the imperative to 'Sound angry.'. This is also repeated, as the gap that develops at line 13 between N1 and N2 is apparently filled with PiC's inaudible talk. At line 16, N1 instantiates N2's guidance by formulating an imperative 'Talk to me:i', for PiC as recipient. N1's delivery is emphatic, at elevated volume, and with slightly rising turn-final intonation. Immediately PiC starts to talk. In this case, N2's advice has been effective: following a sequence of failed summons, $\mathrm{PiC}$ begins to talk immediately after N1 'sounds angry'. Note that N2's intervention does not specify a particular wording or action for N1 to animate but suggests the stance with which her next turn should be delivered. Note further that, in both 
Extracts 3 and 4, like Extract 2, N2s interventions occur in the gaps that emerge following FPPs that do not get SPP uptake from PiC.

Overall, Extracts 3 and 4 show how N2s make interventions on the unfolding interaction by using imperative-formatted suggestions designed to modify the way N1s deliver their turns at talk. This type of intervention is markedly different to those in which $\mathrm{N} 2 \mathrm{~s}$ formulate turns for $\mathrm{N} 1$ to deliver to the $\mathrm{PiC}$ as primary recipient. In the next section, we examine further instances of N2-authored turns for $\mathrm{N} 1$ animation, this time designed for PiC as primary recipient with a requested action for $\mathrm{N} 1$, which are more or less specific in terms of what to repeat. Again, N2s build their intervention into ongoing spates of talk, while remaining backstage.

\section{N2 INTERVENTIONS ON NEXT ACTIONS WITH PiC AS PRIMARY RECIPIENT}

Like Extract 2, Extracts 5 and 6 show how N2 designs turns with imperative components that formulate authored turns for N1's animation. In Extract 5, the PiC is located on top of a roof and the negotiators communicate with him from various locations at the ground level of the building. We join the negotiation as the $\mathrm{N} 1$ proposes the PiC moves to another location on the roof, to enable him to speak to another negotiator, Tracy.

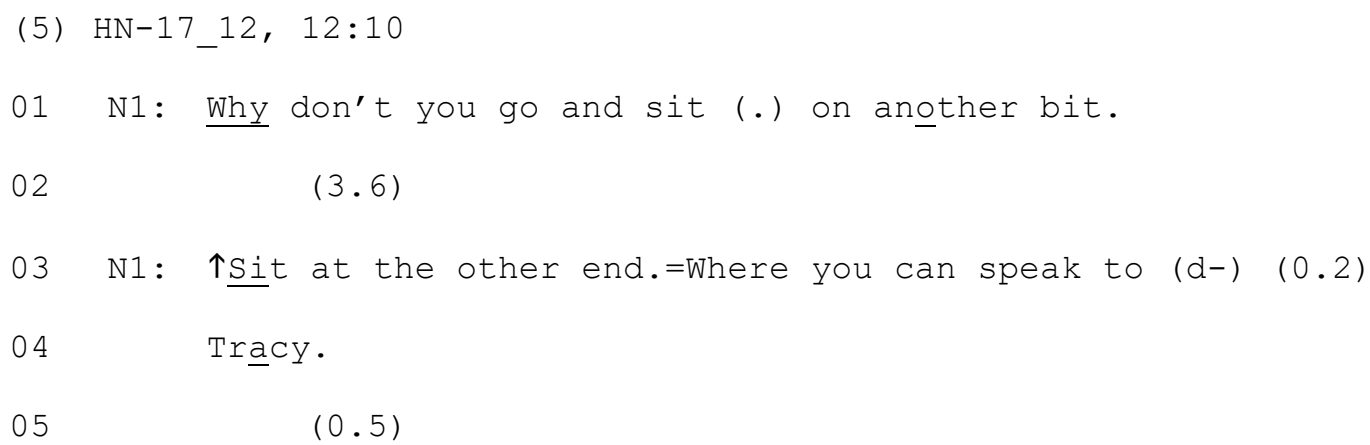




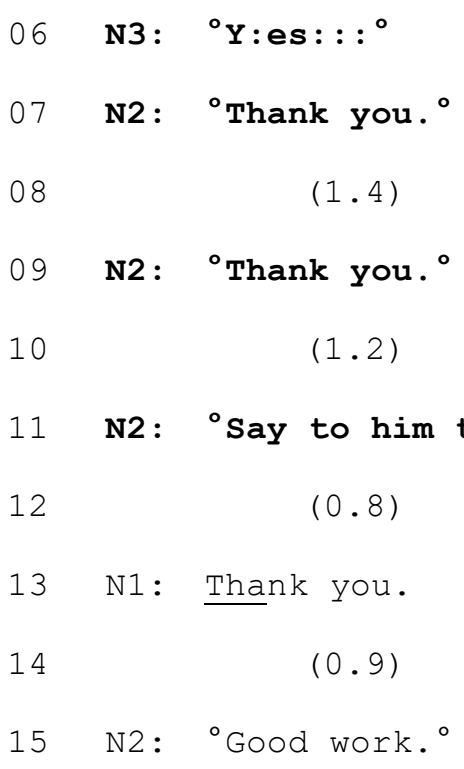

N1's suggestion (line 01) for PiC to sit 'on another bit', is apparently met with resistance. After a long gap develops, N1 instructs PiC to ' $\uparrow \underline{\text { Sit }}$ at the other end.', adding an account in a latched TCU ('=Where you can speak to ... Tracy.'). This time, the PiC apparently embodies compliance in a SPP, given N3's whispered sequence-closing third turn assessment 'oY:es:::' (line 06) - designed for negotiators only to hear.

N1's negotiation is, then, at this point, effective. At line 07 , N2 says ' ${ }^{\circ}$ Thank you. ${ }^{\circ}$ Given that he repeats this at line 09, and then redesigns his turn at line 11, it is clear that N2's first ' ${ }^{\circ}$ Thank you. ${ }^{\circ}$ ' was designed as a turn to be animated by N1. However, until N2 includes the imperative component 'Say to him', it is not treated by N1 as such. Perhaps N1 thinks N2 is appreciating his effective negotiation, or that N1 is resisting N2's suggestion, foregrounding his autonomy and agency. The use of the imperative may analysed as an instantiation of N2's entitlement to direct N1, or as an embodiment of some prior socialinstitutional relationship between the two. However, we also suggest that the use of brief 'say' imperatives is more likely to be oriented to progressivity, and the limited interactional space available to make an intervention as a backstage third party. Quite simply, more 'polite' direction ("Could you say thank you here?"; "Just wondering if you could say thank 
you”) takes more time. Indeed, at line 13, N1 calls, 'Thank you.' to PiC, but it is several seconds after he has complied with N1's instruction and thereby is delayed, like an afterthought. It is unclear whether saying 'thank you' is interactionally consequential; it seems to be lost in the ether as a standalone TCU. At line 15, N2 produces an appreciation of N1's work, making recipiency clear by using different words ('good work') and dispensing with a 'say' imperative.

In Extract 5, the inclusion of 'say to him' disambiguates the action and recipient of N2's turns. In Extract 6, N1 is trying to get PiC to talk to her, and, like N2 interventions in Extracts 2-4, the suggestions are designed to modify N1 FPPs and mobilize responses.

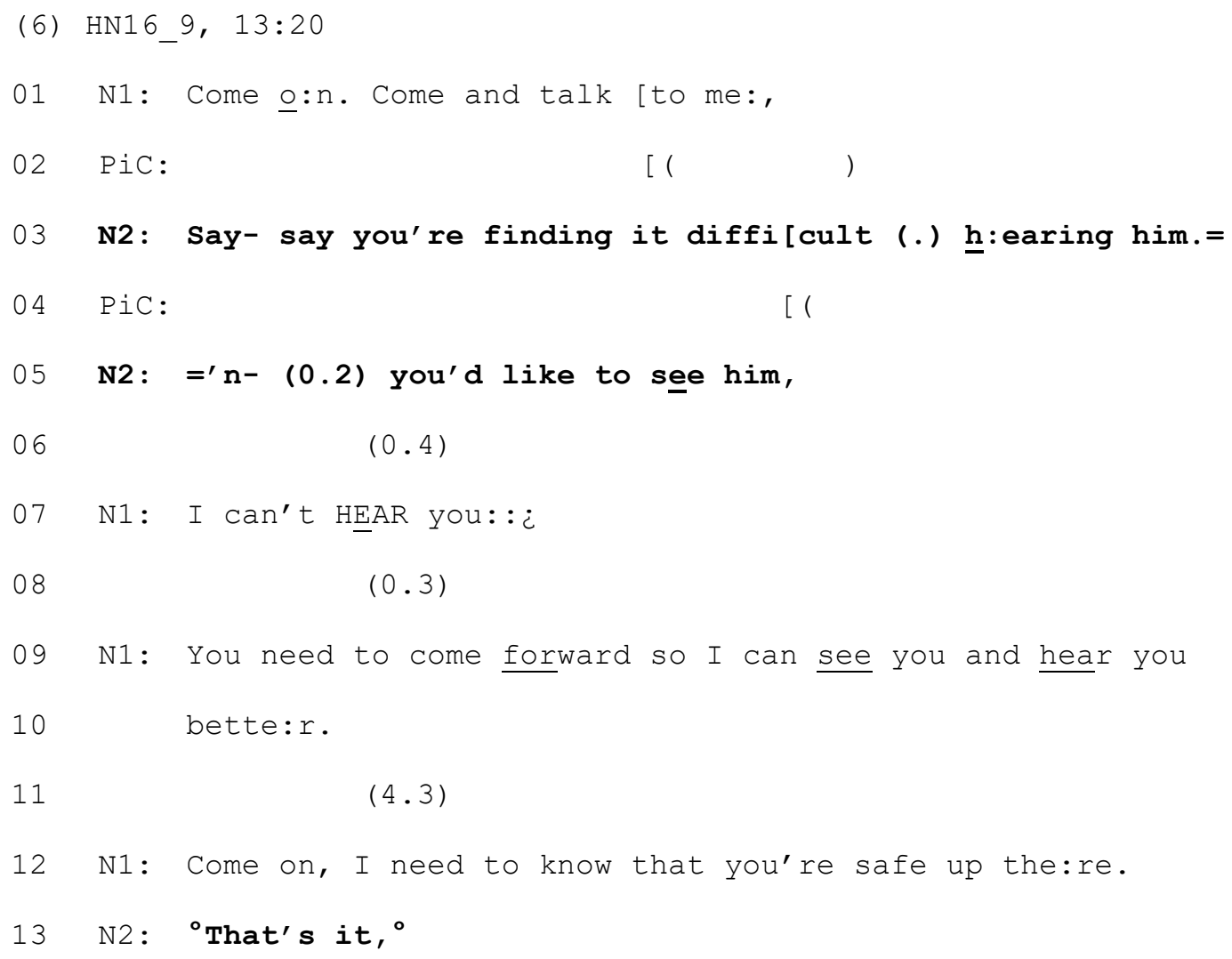

In contrast to Extract 5, N2's say-preface appears at the start of his first suggested turn for N1 to animate, ensuring that $\mathrm{N} 1$ understands its intended recipient. N2's words also require some transformation in footing, from 'you' and 'him' to 'I' and 'you'. N1 animates the function of 
N2's turn, but not its precise design. Note the addition of an account for her imperativeformatted request 'you need to come forward so I can see you and hear you bette:r.' (lines 09-10). After a long gap, N1 pursues a response from PiC ('Come on.'). At line 13, N2 produces a turn designed for N1 (note the whispered volume): 'That's it', which is responsive not to PiC moving, but a positive assessment of $\mathrm{N} 1$ for having said the right sort of thing. While PiC does not 'come forward' for some time, he becomes verbally engaged.

N2's suggestion is placed in a slot that is not overlapping either PiC or N1's talk. It also occurs as N1 has repeatedly requested that PiC 'talks' to her. We have found that proposals and requests to 'talk' are routinely resisted in these negotiations, on the basis that 'talk does not do anything' (Sikveland and Stokoe forthcoming). Whether or not this is the tacit expertise $\mathrm{N} 2$ displays here, his intervention is precisely timed, in terms of sequential position, and offers a change of strategy when a repeated request has failed.

In Extract 7, N2 adds 'try' to his say-prefaced turn, which reduces the constraint for N1 to formulate a direct repetition of whatever N2 suggests.

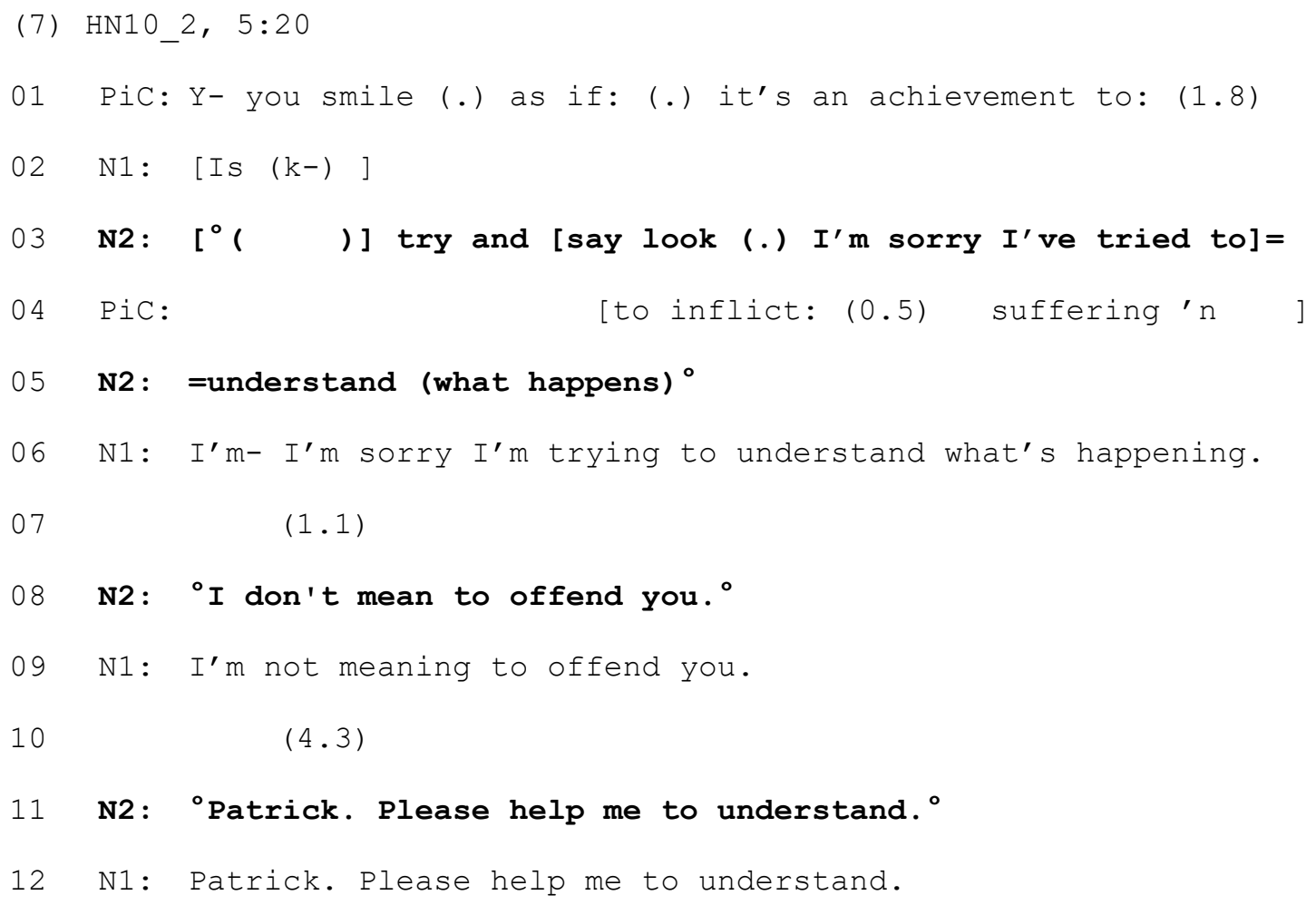


16 N1: What's happened.

N2's suggestion is that N1 account (which is difficult to hear) for some earlier offence taken by Patrick and apologize for it (lines 03-08). While there are subtle differences between N2's suggestions and N1's subsequent animations, N1 largely repeats N2's authored turns. He also uses similar intonation and phrasal prominence patterns as N2, who produces a 'reading' voice comprised of global rise-fall across each intonation unit. Furthermore, unlike previous examples, N2 does not place his turns 'in the clear', but in overlap with both N1 and PiC's ongoing turns.

The analysis above shows how N2s instruct and guide N1s to animate the turns they author for PiCs as recipient. N2s suggest sequence-closing third turns (Extract 5) and accounts for N1 actions, including FPP requesting turns that do not get uptake from PiCs (Extracts 6 and 7). The inclusion of a say-preface to imperative suggestions clarifies intended recipiency, as shown by its inclusion after previous failed attempts to get N1 to say what N2 suggests. The impact of N2 suggestions varies across our three cases. In Extract 5, N1's animation of N2's 'thank you' resulted in a standalone TCU, disconnected from its sequential fit to PiC's actions. In Extract 6, N2's interventions appear apposite and effective, in that a positive shift in PiC's behaviour occurs almost immediately. In Extract 7, we saw little impact of N2's interventions to mobilize a response from the PiC. In the final section, we consider how $\mathrm{N} 2$ interventions, particularly those targeting $\mathrm{PiC}$ as recipient, may be fitted and apposite (or inapposite and ill-fitted) to the frontstage unfolding interaction, in terms of their sequential position and action. 


\section{INAPPOSITE BACKSTAGE N2 INTERVENTIONS}

The suggestions made by N2 may aid ongoing negotiation but also risk derailing it temporarily for a small number of turns, or in a more sustained way by, say, initiating or escalating conflict. Extract 8 comes from the same case as Extracts 4 and 6 . We join the negotiation approximately an hour into the four hours it runs overall, as N1 attempts to elicit the PiC's name - something that she has pursued earlier. Some of PiC's talk across lines 0506 and 13 is difficult to hear.

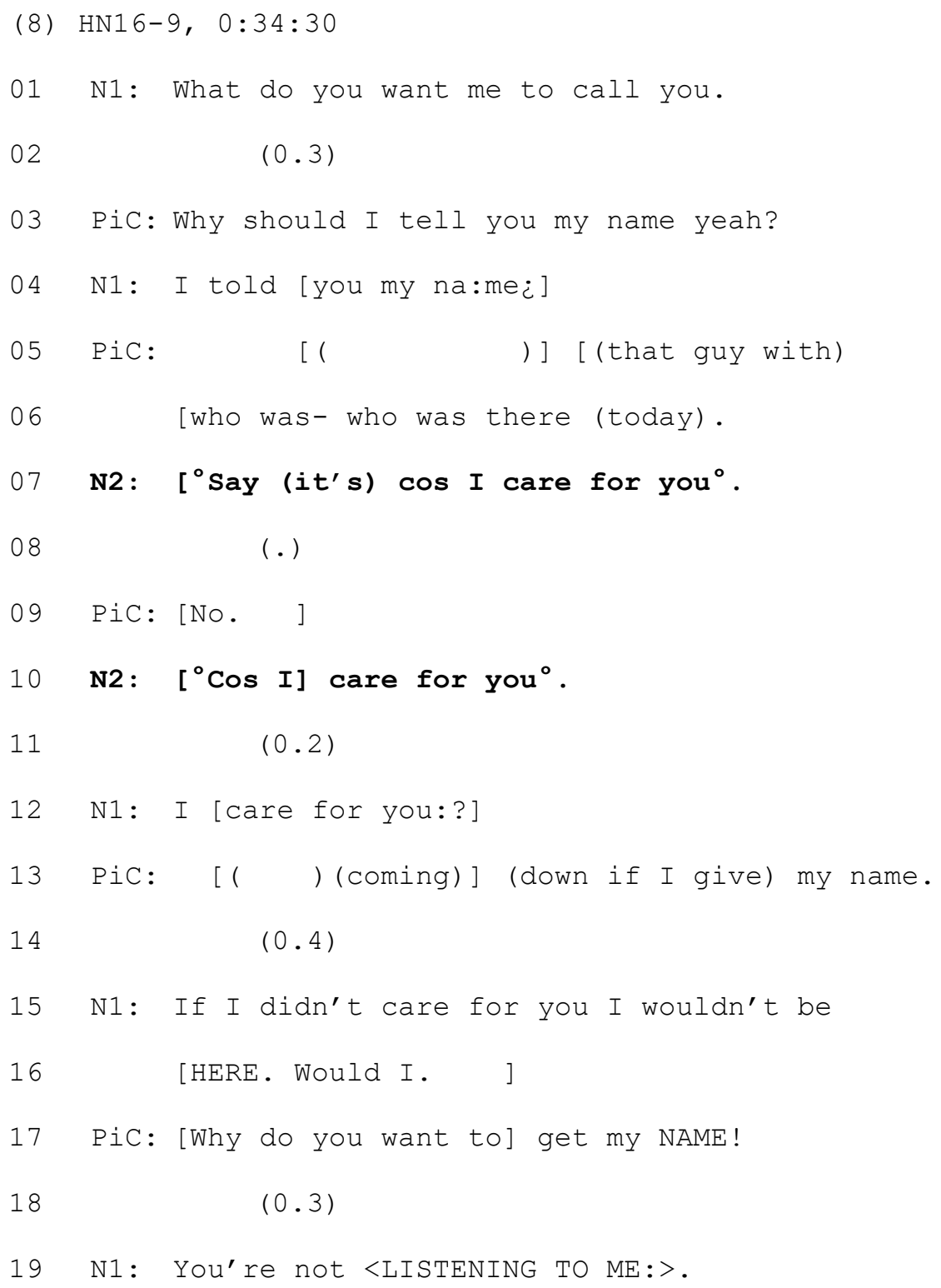


At the start of the episode, N1 does not, in fact, ask PiC for his name, but what he wants her to 'call' him. Our data show that PiCs often resist supplying their name (including surname) for many reasons, including (as in this case) following earlier criminal activity and pursuit from police (cf. Sacks 1992, on how callers to a Suicide Prevention Center avoid giving their names). Given that N1 has not asked for PiC's name, one possible response to PiC's resistance is reassurance - that he does not have to give his (full) name. Instead, N1's response invokes a reciprocal obligation for mutual sociality ('I told you my na:me ¿’): PiC has started talking almost as N1 responds with a largely inaudible turn.

At line 07, N2 formulates a say-prefaced candidate account ('say (it's) cos I care for you') to PiC's objection to the original request ('Why should I tell you my name yeah?'). PiC's objection is the FPP of an insert expansion; N1's SPP ('I told you my na:me $¿$ ') appears to get no traction. $\mathrm{N} 2$ repeats his suggestion, this time dispensing with its say-preface $\left({ }^{\circ} \mathrm{Cos} \mathrm{I}\right.$ care for $\mathrm{you}^{\circ}$ ) but treating $\mathrm{N} 1$ as able to hear this as a turn to animate for PiC as the primary recipient (and not an expression of care from N2 to N1). As discussed in our analysis of Extract 5, it may be tempting to read a power differential in the relationship between $\mathrm{N} 2$ and $\mathrm{N} 1$, and N2's entitlement to direct the talk of N1. However, it is more likely that N2 repeats his suggestion because it is initially produced in overlap (lines 06-07). After a short gap at line 11, N1 animates N2's backstage SPP. We do not know if N1 has heard N2's suggestion both times it was produced, or whether she initially resisted animating it. She may have heard both imperatives but waited for a clear TRP in which to produce it. She may also have heard both and thus in its production reveals her tacit analysis of the unfolding sequence: N1 does not include 'cos' in the turn at line 12: 'I care for you:?'. Although N2 authored a candidate SPP response to PiC's question at line $02, \mathrm{~N} 1$ does not produce it as a SPP, but as a new FPP. By dropping the 'cos', N1 orients both to the progressivity of her interaction with PiC as recipient and the ill-fitted suggestion supplied by $\mathrm{N} 2$. 
PiC starts talking in overlap with N1's new FPP, continuing to extend the earlier sequence and maintaining his objection to giving his name (line 13). N1 continues to expand and account for the 'care' element she has animated which was authored by N2: 'If I didn't care for you I wouldn't be HERE. Would I.' Again, however, PiC talks in overlap, reissuing and reformulating his earlier question: 'Why do you want to get my NAME!' (line 17). This shows that the intervening talk has disrupted the progressivity of the sequence; N2's suggestions have not resulted in a response that removed the need for PiC to reissue his question. It is somewhat ironic, then, that the sequence ends with N1 chastising PiC for not 'listening'.

Extract 8 shows the potential complexities involved in crisis negotiation. When the N1 and PiC are already talking in overlap, N2 interventions create problems for recipiency and progressivity. Crisis negotiation opens a double participation framework for N1 who must interact with PiC and N2. In the case above, N2's turns disrupt the N1-PiC interaction, in terms of unfolding sequential organization and action. Extract 9 is structurally less complex but illustrates further inapposite interventions from N2. The case comes from the same negotiation as Extract 3, in which the PiC, Jessica, is inside her house and stood on a chair with a noose around her neck. The negotiators are outside, within visible and audible range as they can see and hear Jessica through a locked security gate, to which PiC has the keys.

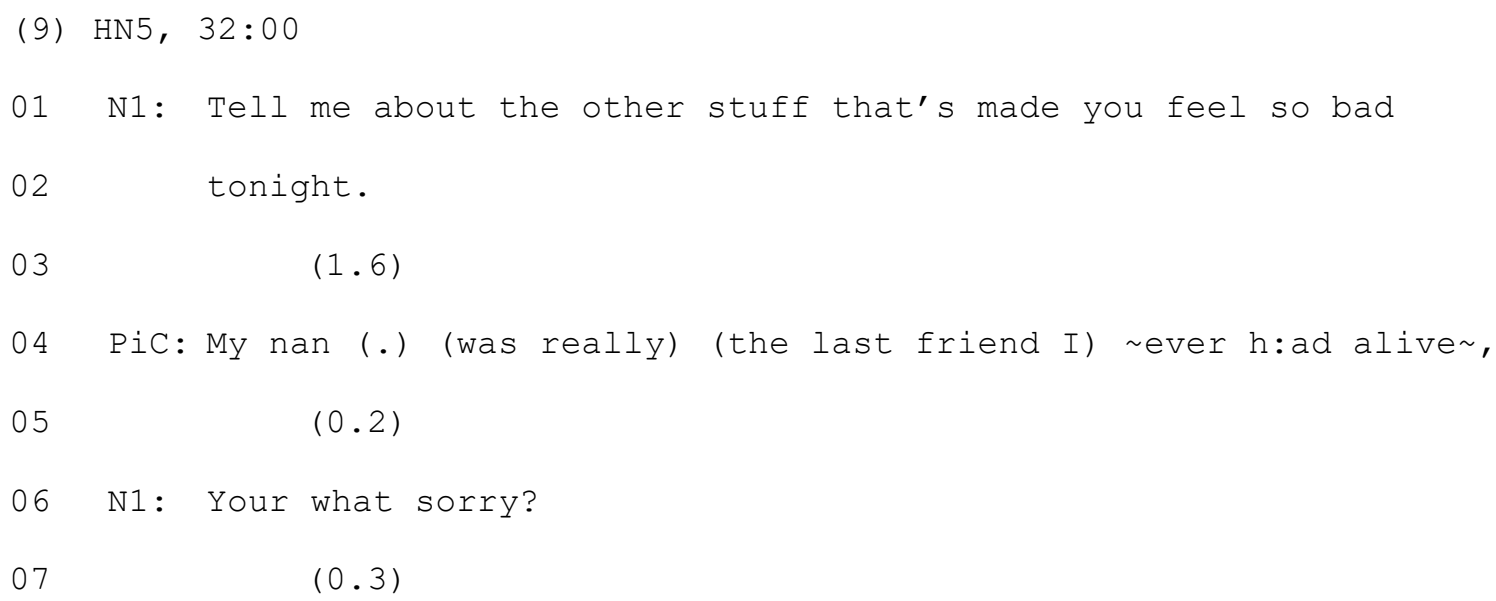




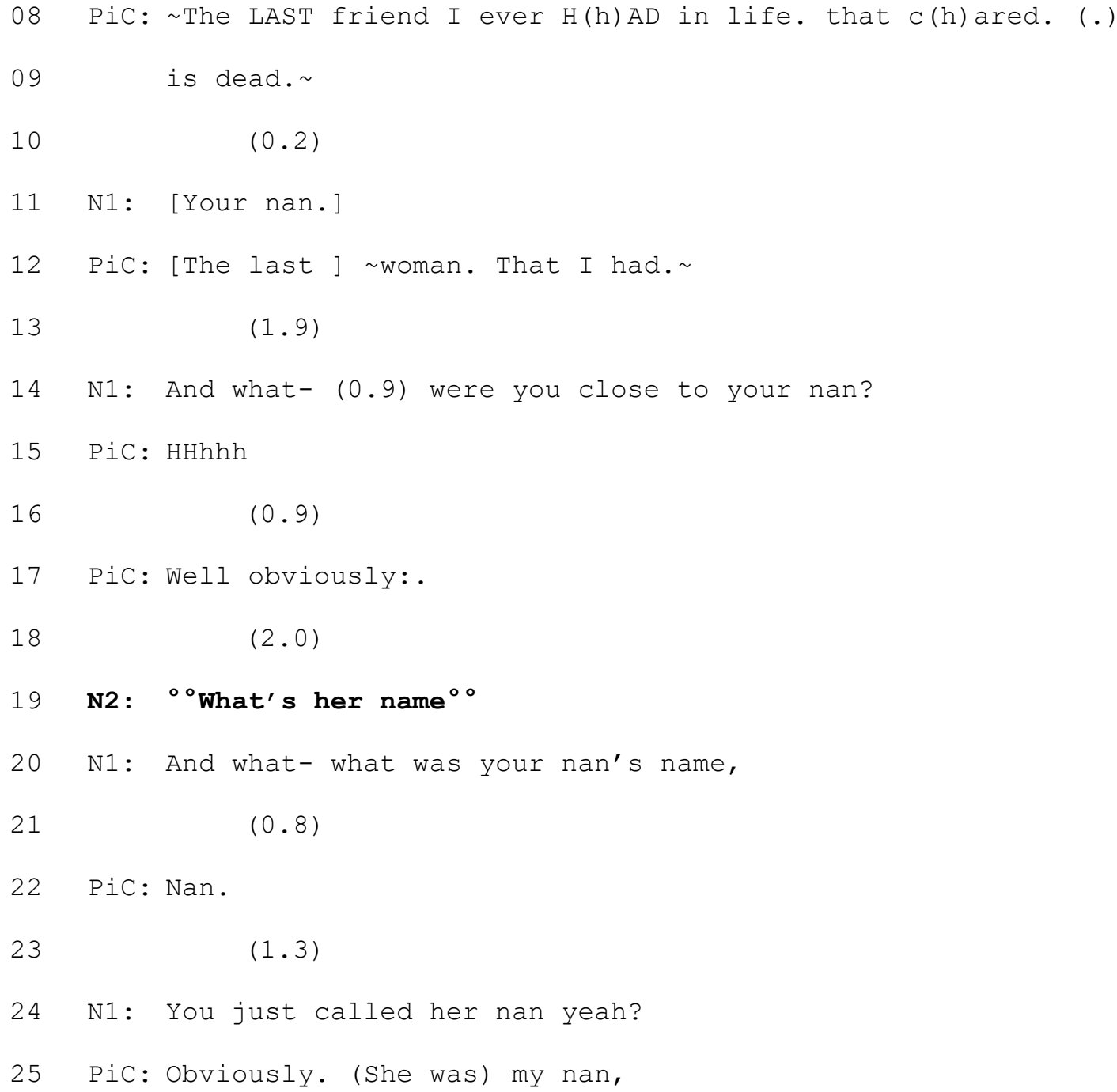

This episode begins effectively, as Jessica produces a fitted narrative response to N1's opening elicitation. We found that wh- or interrogative formatted questions containing a timeframe (line 01: 'Tell me ... so bad tonight') routinely mobilized responses from Jessica, particularly after spates of conflict or resistance to talking. After a delay, Jessica produces a preferred SPP - an answer to N1's question. This is an example of the kind of delayed preferred response we mentioned earlier. The delay works to create distance between the FPP and SPP, such that Jessica's turn is not 'too responsive' to N1; foregrounding her agency in a decision to talk, not simply agreeing to N1. For negotiators, Jessica's answer is exactly the kind of response they seek, as it discloses 'type 1 knowable' (Pomerantz 1980) information about Jessica and suggests a willingness to participate productively in the negotiation. 
At line 06, N1 initiates repair, having apparently not heard Jessica's emotion-laden response. At line 08, Jessica reformulates and slightly upgrades her response, which is produced at higher volume, with extreme case formulations, increased breathiness and 'wobbly voice' (Hepburn 2004). N1 initiates repair again (line 11), in overlap with Jessica, who produces a second partial repeat of her initial response (line 12). After a long gap, N1 asks a question that Jessica treats as inapposite. Having disclosed the loss of her nan, the 'last friend' she 'ever had in life', N1 asks if Jessica was 'close' to her grandmother. Jessica's response to sign and confirm that she was close to her nan while challenging the askability of the question: 'Well obviously:.'.

At line 18, another long gap develops, after which N2 supplies a turn for $\mathrm{N} 2$ to animate. The selection of this location reveals N2's ongoing analysis of the emerging disfluency and misalignment in the sequence, after a promising start. In this case, N2 does not use a saypreface or other turn design features, but simply whispers 'ooWhat's her name ${ }^{\circ \circ}$ (line 19). N1 immediately animates the action as a first pair part directed at Jessica, replacing 'her' with 'your nan' and initiating the turn with an and-preface to connect it to N1-PiC prior talk. After a delay, Jessica responds. The delay and delivery indicate further emerging disaffiliation between Jessica and N1; after another delay, N1 asks another question that Jessica treats as having an already-known answer, and thus inapposite (cf. Stokoe and Edwards 2008, on 'silly questions'): 'You just called her nan ... Obviously she was my nan'.

The final section has described instances in which N2 interventions disrupt the progressivity of the negotiation or are misaligned with the PiC's turns. When compared to interventions for which $\mathrm{N} 1$ is the primary recipient, it appears that suggesting candidate turns for $\mathrm{N} 1$ to animate is a riskier practice. We consider our accumulated findings in the next section. 


\section{DISCUSSION}

A basic goal of hostage and crisis negotiation is to keep person in crisis taking turns, and, with each turn taken, choosing life. The aim of this paper was to scrutinize the methods negotiators use to engage persons in crisis and, ultimately, initiate and maintain productive sequences of talk. Our analysis focused on how secondary negotiators intervened in ongoing conversations between persons in crisis and primary negotiators, while remaining in the 'backstage' and not taking turns directly in the negotiation. While many of the observed actions fell broadly into the categories of N2 actions described previously by McMains and Mullins (2014) - 'develop verbal tactics' and provide 'moral support' - our analysis has specified these empirically. $\mathrm{N} 2$ actions fell broadly into those designed for $\mathrm{PiC}$ as recipient in cases where $\mathrm{N} 2$ authors turns for $\mathrm{N} 1$ to animate, and those designed for N1 as sole recipient. However, we also saw that a suggestion from N2 for N1 to 'keep calm' has the PiC as its ultimate recipient if $\mathrm{N} 1$ modifies the delivery of their turns.

The data analysed illustrate the range of sequential environments in which $\mathrm{N} 2 \mathrm{~s}$ take turns and the actions they form: suggesting alternate or modified first pair parts to encourage PiCs to respond in cases where N1's actions (e.g., questions, summons) did not mobilize a response; suggesting accounts for N1-produced first pair parts (e.g., 'say you're finding it difficult to hear'); suggesting answers to PiC questions, and suggesting sequence-closing appreciations when PiCs produced preferred responses (e.g., 'thank you'). We found that negotiators oriented to and often pre-empted the problem of recipiency by prefacing their authored turns with 'say' or 'try and say'. When such prefaces were absent from turn design, N1s did not always understand who the intended recipient of, say, 'thank you' was. Overall, we found that N2-authored turns were more common than the limited guidance for the role suggests, as a 'coach', 'permitting ventilation and sharing the stress' (Schlossberg 1980), to 
'provide moral support' (McMains and Mullins 2014), and to 'assist, listen, gather intelligence' (Greenstone et al 2000). While some recommend that N2s 'monitor the verbal interactions' (ibid.:397), and 'help develop verbal tactics' (McMains and Mullins 2014), it is only now that we can shed light onto what such guidance translates into, in terms of actual linguistic practices. Our analysis has also identified ways in which speakers work in concert that are different to, say, choral or compound TCU production or other forms of orchestration previously researched in conversation analysis (e.g., Lerner 2002).

The institutional setting of crisis negotiation, involving a third behind-the-scenes interlocutor in a two-party interaction, provides the basis for further examining how 'members', in the ethnomethodological sense, make everyday life accountable. Unlike interactions where all parties are (potentially) 'frontstage', the job of the secondary negotiator (N2) is to suggest to the primary negotiator (N1) what, how, and when to say particular words formulated as actions - while remaining 'hidden' from the recipient of those turns. We have shown that, while the $\mathrm{N} 2$ is often visible to the $\mathrm{PiC}$, all parties collaborate to maintain $\mathrm{N} 2$ in the backstage, although there are exceptions:




The PiC is located on roof outside his flat, carrying a knife; the negotiators are on the ground below. Here, PiC topicalizes N2's backstage turns ('Is the person whispering: (0.2) saying the things that you're saying.'), and the possibility that he is authoring turns for N1 to animate. $\mathrm{N} 1$ partly resists the implication of PiC's question and involves the formal role of $\mathrm{N} 2$ in accounting for N2's participation ('we say things that may help, may assist, we talk to each other.'). Overall, however, regardless of the perceptual availability of N2 to PiC, our data show that all parties mutually reinforce N2's behind-the-scenes role.

$\mathrm{N} 2$ turns reveal the tacit knowledge that members have about how conversation works. To take a turn, N2 displays their understanding of turn construction, action, prosody, and sequence - as also displayed in the ongoing encounter between N1 and PiC. As we have seen, $\mathrm{N} 2 \mathrm{~s}$ make both effective and inapposite suggestions for N1 to formulate as turns at talk with PiCs. Some N2-authored turns were effective in progressing the goal of negotiation: getting $\mathrm{PiC}$ to take productive turns in the negotiation process. Other N2-authored turns were illfitted as responsive or initiating actions, temporarily halting progressivity. The ineffectiveness of N2-authored turns is often revealed by PiC's subsequent turns, which assessed or otherwise challenged what N1s said. Given that the job of conversation analysts is to analyse, not evaluate, social interaction - it helps when assessments are endogenous to the interaction itself, as in Extract 11.

(11) HN32, 24:09

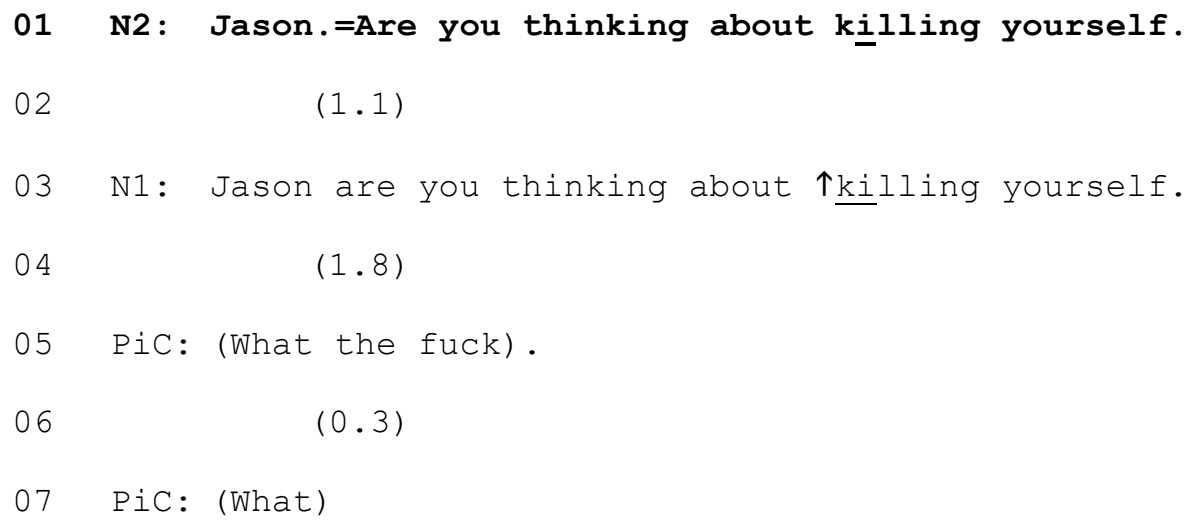


After a delay (line 04), Jason initiates an insert expansion FPP ("What the fuck"), which also has change-of-state and pre-turn qualities. Like the PiC in Extract 9, but with more disaffiliation, Jason challenges the askability of the question, "are you thinking about $\uparrow \underline{\text { killing }}$ yourself.". Indeed, after further delay (line 08), he produces another wh- (rhetorical) question, "What you talking shit for.". The format carries multiple functions, including negatively assessing the quality of N1's turn (and thus N2's intervention) and its appositeness. The research presented in this paper underpinned communication training for police negotiators in the UK and internationally (Stokoe 2014; Stokoe \& Sikveland 2017). Indeed, this project was initiated and funded by a hostage and crisis unit with training as a goal. N2s are particularly and peculiarly 'trainable', as they are not obliged to participate in the frontstage encounter and have more interactional space to formulate potential actions. By training negotiation teams (as all members enact and rotate through N1-N4 roles) with the kinds of extracts presented above, N2s may be better able to enact their role.

In sum, our paper has opened up crisis negotiation for further empirical scrutiny showing particularly how N2s actually enact their role in the negotiation team. We have focused on the encounters police negotiators have with persons in crisis, some of the most critical conversations any professional person might have. Discovering what works and what is less effective in such encounters helps negotiators to understand their practice, with the goal for stressful encounters to nevertheless be as smoothly progressing as they can ever be. It is a project ideally suited to conversation analysis as a methodology and theory of social interaction, providing evidence of a different kind for the systematic organization of talk as oriented to by members' ongoing analysis of the mutual coordination and production of social life. 


\section{ACKNOWLEDGEMENTS}

We are grateful to Marco Pino, our anonymous reviewers, and the Editors, for their helpful comments on earlier drafts of this paper.

\section{REFERENCES}

Agne, Robert R. 2007. Reframing practices in moral conflict: interaction problems in the negotiation standoff at Waco. Discourse and Society, 18 (5): 549-578.

Champe, Julia and Kleist, David M. 2003. Live supervision: A review of the research. The Family Journal, 113: 268-275.

Charlés, Laurie L. 2007. Disarming people with words: Strategies of interactional communication that crisis hostage negotiators share with systemic clinicians. Journal of Marital and Family Therapy, 33/1: 51-68.

Emerson, Kathryn, Williamson, Victoria and Wilkinson, Ray. 2017. Seeing the music in their hands: How conductors' depictions shape the music. In E. Van Dyck Ed., Proceedings of the 25th Anniversary Conference of the European Society for the Cognitive Sciences of Music, 31 July-4 August 2017, Ghent, Belgium.

Garcia, Angela. 2017. What went right: Interactional strategies for managing crisis negotiations during an emergency service call. The Sociological Quarterly, 58 (3): 495518.

Goffman, Erving. 1981. Forms of talk. Philadelphia, PA: University of Pennsylvania Press.

Greenstone, James L., Kosson, David S. and Gacono, Carl B. 2000. Psychopathy and hostage negotiations: Some preliminary thoughts and findings. In Carl B. Gacono Ed. The Clinical and Forensic Assessment Of Psychopathy. London: Routledge. 385-404. 
Hepburn, Alexa. 2004. Crying: Notes on description, transcription, and interaction. Research on Language and Social Interaction, 373: 251-290.

Heritage, John. 2005. Conversation analysis and institutional talk. In Kristine L. Fitch and Robert E Sanders eds. Handbook of Language and Social Interaction. Mahwah, New Jersey: Lawrence Erlbaum Associates. 103-147.

Jefferson, Gail. 2004. Glossary of transcript symbols with an introduction. In Gene H. Lerner ed. Conversation Analysis: Studies from the First Generation.

Amsterdam/Philadelphia: John Benjamins. 13-31.

Keevallik, Leelo. 2010. Bodily quoting in dance correction. Research on Language and Social Interaction, 43 (4): 1-26.

Knowles, Gordon James. 2016. Social psychological dynamics of hostage negotiation: Forensic psychology, suicide intervention, police intelligence/counterintelligence, and tactical entry. Journal of Criminal Psychology, 6(1): 16-27.

Koskela, Inka and Palukka, Hannele. 2011. Trainer interventions as instructional strategies in air traffic control training. Journal of Workplace Learning, 23 (5): 293-314.

Kyunghee, Suh. 2016. 'I mean' as a marker of 'interpersonal repair' in crisis negotiation. The Sociolinguistic Journal of Korea, 243: 223-247.

Lerner, Gene H. 2002. Turn-sharing: The choral co-production of talk-in-interaction. In Barbara A. Fox, Cecilia E. Ford and Sandra A. Thompson eds. The Language of Turn and Sequence. New York: Oxford University Press. 225-257.

Mazeland, Harrie. 2007. Parenthetical sequences. Journal of Pragmatics, 39 (10): 1816-1869.

McMains, Michael J. and Mullins, Wayman C. 2014. Crisis negotiations: Managing critical incidents and hostage situations in law enforcement and corrections $5^{\text {th }}$ edition. Waltham, MA: Anderson Publishing.

Montavlo, Braulio. 1973. Aspects of live supervision. Family Process 12(4): 343-359. 
Noesner, Gary W. and Webster, Mike. 1997. Crisis negotiations as crisis intervention. In Stephen J. Romano and M F. McCann eds. Crisis negotiations: A compendium. Quantico, VA: Crisis Negotiation Unit, Critical Incident Response Group, FBI Academy. 3-19.

Olson, Ulf-Johan and Pegg, P.F. 1979. Direct open supervision: A team approach. Family Process, 18: 463-9.

Peräkylä, Anssi. 1995. AIDS counselling: Institutional interaction and clinical practice. Cambridge, UK: Cambridge University Press.

Peräkylä, Anssi and Vehviläinen, Sanna. 2003. Conversation analysis and the professional stocks of interactional knowledge. Discourse and Society, 14 (6): 727-750.

Pomerantz, Anita. 1980. Telling my side: 'Limited access' as a fishing device. Sociological Inquiry, 50 3-4: 186-198.

Royce, Terry. 2005. The negotiator and the bomber: Analyzing the critical role of active listening in crisis negotiations. Negotiation Journal, 21 (1): 5-27.

Rubin, Gabriela B. 2016. Negotiation power through tag questions in crisis negotiations. Unpublished PhD thesis, Washington, DC: Georgetown University.

Sacks, Harvey. 1992. Lectures on Conversation Vols I and II, edited by Gail Jefferson. Oxford: Blackwell.

Sacks, Harvey, Schegloff, Emanuel A., and Jefferson, Gail. 1974. A simplest systematics for the organization of turn-taking for conversation. Language, 50 (4): 696-735.

Schlossberg, Harvey. 1980. Values and organization in hostage and crisis negotiation teams. Annals of the New York Academy of Sciences, 347: 113-116.

Schwartz, Richard C., Liddle, Howard A. and Breunlin, Douglas C. 1988. Muddles in live supervision. In Howard A. Liddle, Douglas C. Breunlin and Richard C. Schwartz eds. 
The Guilford Family Therapy Series. Handbook of Family Therapy Training and Supervision. New York, NY, US: Guilford Press. 183-193.

Sikveland, Rein Ove. 2019. Failed summons: Phonetic features of persistence and intensification in crisis negotiation. Journal of Pragmatics. doi: 10.1016/j.pragma.2019.01.023

Sikveland, Rein Ove and Stokoe, Elizabeth. forthcoming. Verbs of engagement: Talk or speak? Word selection and resistance in crisis negotiations. Manuscript under review.

Silverman, Manuel S. and Quinn, Philip F. 1974. Co-counseling supervision in practicum. Counselor Education and Supervision, 13 (4): 256-260.

Stokoe, Elizabeth. 2014. The Conversation Analytic Role-play Method CARM: A method for training communication skills as an alternative to simulated role-play. Research on Language and Social Interaction, 47 (3): 255-265.

Stokoe, Elizabeth and Edwards, Derek. 2008. 'Did you have permission to smash your neighbour's door?' Silly questions and their answers in police-suspect interrogations. Discourse Studies, 10 (1): 89-111.

Stokoe, Elizabeth and Sikveland, Rein Ove. 2017. The Conversation Analytic Role-play Method: Simulation, endogenous impact and interactional nudges. In Sarah Pink, Vaike Fors, and Tom O’Dell eds. Theoretical Scholarship and Applied Practice. Oxford: Berghahn Books. 73-96.

Stokoe, Elizabeth, Sikveland, Rein Ove, Kevoe-Feldman, Heidi and Humă, Bogdana. 2018. Delayed preferred responses: Being persuaded following resistance in initially misaligned encounters. Paper presented to NORDISCO, Aarhus, Denmark.

Strenz, Thomas. 2017. Psychological Aspects of Crisis Negotiation $3^{\text {rd }}$ edition. New York: Routledge. 
Vecchi, Gregory M., Van Hasselt, Vincent B. and Romano, Stephen S. 2005. Crisis hostage negotiation: Current strategies and issues in high-risk conflict resolution. Aggression and Violent Behaviour 10: 533-551.

Voss, Christopher and Raz, Tahl. 2016. Never Split the Difference: Negotiating As If Your Life Depended On It. Random House.

Weeks, Peter. 1996. A rehearsal of a Beethoven passage: An analysis of correction talk.' Research on Language and Social Interaction 29 (3): 247-290. 


\section{APPENDIX: TRANSCRIPTION CONVENTIONS}

The symbols used in this article are adapted from Gail Jefferson's transcribing conventions.

Symbol Definition

.hh hh Inhalations and exhalations, respectively

Spee::ch Colon indicates a syllable that is drawn out

To- $\quad$ Dash indicates a word has been cut off abruptly

Very Underlining indicates stress or emphasis

(1.4) Numbers in parentheses indicate length of pauses (in seconds)

.¿¿ $\quad$ Punctuation indicates intonation at the end of units of talk. Full stop stands for falling intonation, comma for flat intonation, reverse question mark for slight rise, question mark for sharp rise in intonation.

[yeah]

[okay] Square brackets represent overlapping talk

$=\quad$ End of one turn and beginning of next begin with no gap/pause in between (usually a slight overlap if there is speaker change)

(words) A guess at what might have been said if unclear

wo(h)rds Within-speech breath-bursts (laughter)

WORD Talk produced loudly in comparison with surrounding talk

Degree signs enclose talk that is produced quietly in comparison with surrounding talk 